\title{
The Relationship Between Discipline and Motivation on Employee Performance Through Mediation of Job Satisfaction
}

\author{
A. Ratna Sari Dewi ${ }^{1}$, Muhammad Fachmi ${ }^{2}$, Gunawan Bata Ilyas ${ }^{3}$, Heriyanti Mustafa ${ }^{4}$ \\ \{ratna_fe@unhas.ac.id ${ }^{1}$, muhammadfachmi22@gmail.com ${ }^{2}$, fadelgun@yahoo.co.id ${ }^{3}$, \\ nurul.fakhira@yahoo.com ${ }^{4}$ \} \\ Faculty of Economics and Business, Hasanuddin University, Indonesia ${ }^{1}$, Faculty of \\ Economics, Amkop College of Economics of Makassar, Indonesia ${ }^{2,3,4}$
}

\begin{abstract}
Job satisfaction in this research wants to see to what extent the role of job satisfaction in mediating the influence between work discipline and motivation on employee performance. This research was conducted on Bank employees in Makassar City, with a sample size of 135 respondents. Hypothesis testing is carried out using the AMOS-path analysis technique, and to identify the indirect effect the researcher also uses the sobel test. The results of the research can be concluded that the higher the discipline and work motivation, the job satisfaction of the employees will increase significantly. On the other hand, higher employee performance is influenced by significantly higher discipline and job satisfaction. However, it is different from work motivation that is not strong enough to affect employee performance improvement. Furthermore, the researcher found that job satisfaction was able to significantly mediate the effect of work discipline and motivation on employee performance.
\end{abstract}

Keywords: Employee Performance, Job Satisfaction, Discipline, Work Motivation

\section{Introduction}

In this era of globalization, it requires precise, fast, and accurate data and information that will support management in the business world's decision-making process. However, in reality, a company will always need the support and participation of other people or employees to achieve the company's goals or organization. As one of the human resources who have a central position for the company, employees are required to be able to produce optimal performance in every activity they have carried out. Moreover, employees in a company play an important role in creating a competitive advantage over other companies [1].

Employee performance is not just thoughts related to one area. Rather it is a concept that focuses on general employee life satisfaction. This is an important issue that reflects the provision of a satisfying and safe environmental factor in the workplace, which is reflected in employees and contributes to achieving organizational strategic goals [2]. Employee performance has a prominent and visible role in any organization's progress and its development 
because employees contribute to its success and effectiveness [3]. Employee performance has a prominent and visible role in any organization's progress and its development because employees contribute to its success and effectiveness [3]. In this case, efforts to improve employee performance can be carried out in various ways, such as determining the right salary for each job and the ability of employees to analyze work independently [4].

One important factor in producing better employee performance is paying attention to employee job satisfaction. According to Rivai and Sagala (2009) [5], job satisfaction is an assessment that reflects someone is feeling happy or unhappy, satisfied, or dissatisfied in taking a job. Job satisfaction reflects a person's feelings about his job. This can be seen in employees' behavior and attitudes in everyday life, usually shown in terms of positive responses at work. Empirically, [6] have conducted research in examining the effect of job satisfaction on employee performance, where the results show that job satisfaction is very important to improve because it will affect employee performance. Likewise, in research conducted [7]-[9] found in their research that job satisfaction has a positive and significant effect on employee performance.

The discipline itself is also one of several factors that affect employee performance. Because without discipline, all activities that will be carried out will produce unsatisfactory results and are not in accordance with expectations. Employee discipline is the behavior of a person according to the rules, existing work procedures or discipline is the attitude, behavior, and actions by the organization's rules, both written and unwritten [10]. Research conducted [7], [11], [12], which revealed that applying good discipline will significantly improve employee performance. However, some things need to be considered. Doing something requires satisfaction with the work it does so that when discipline is high and is followed by high job satisfaction, employee performance will also increase.

An important factor that can also affect employee performance is work motivation. The emergence of motivation in a person is determined by the existence of employees' needs both in the form of primary needs and secondary needs. If employees' needs are met, then someone will be more active in working, and the result is that they will be able to improve the employee's performance. With high motivation, it will encourage employee performance to be higher. Motivation is a boost to a series of human behavior processes in achieving goals [13]. Previous researchers believed that high performance was influenced by employees' increasing work motivation [14]-[16]. Larasati, and Gilang (2014) in their research, concluded that work motivation has a positive and significant effect on employee performance [17]. This means that the higher the employee's motivation, the higher the performance that will be generated by the employee.

Although empirically, there have been many studies that prove that work discipline and motivation will increase employee satisfaction and performance, there are still several studies that provide different findings. Among them are Paoki et. al (2017) and Sadjana et. al (2019) that work discipline was found to have no significant impact on improving employee performance [18], [19]. Then in research conducted by Dermawan et. Al (2018) motivation does not significantly affect employee performance, which means that even though employees have good work motivation, it does not have a significant effect or have a small effect on improving employee performance [20].

This research was conducted in the banking industry in Makassar City, where generally employee performance has been good. Nevertheless, it is necessary to do an empirical study to prove whether the existence of work discipline and motivation, coupled with high job satisfaction from employees, will be able to improve employee performance or not. This is because there are still gaps between theory and facts from various previous researches, so this 
research needs to be done to fill this gap. Therefore, researchers are interested in conducting a study entitled "Discipline and Work Motivation on Employee Performance: The Mediating Role of Job Satisfaction".

\section{Method}

The research carried out is quantitative research by obtaining data in the form of numbers or qualitative data, which are estimated. Based on the explanation level, this research includes associative research in which a theory can be built that can serve to explain, predict, and control a phenomenon that occurs.

This study's population were all employees in the banking industry in Makassar City, where the researchers took four banks to serve as sample companies, namely Bank BCA, Bank BRI, Bank BNI, and Bank Mandiri. The number of samples in this study was 135 respondents. The sampling technique in this study used a random sampling technique, in which researchers distributed questionnaires online with Google Form and distributed to all employees at four banking companies in Makassar City.

This study consists of four variables, namely work discipline with indicators: attendance, work procedures, obedience to superiors, work awareness, and responsibility [21]. Work motivation variables with indicators: decent wages/salaries, providing incentives, fulfilling participation needs, placing employees inappropriate places, and paying attention to the workplace environment [22]. Job satisfaction variables are measured by indicators of: fair and proper remuneration, appropriate placement according to expertise, work atmosphere, equipment that supports work implementation, and the leader [23]. Moreover, employee performance variables are measured by indicators: work quality, work quantity, responsibility, initiative, and cooperation [24].

The data analysis technique used in this research is path analysis using AMOS software. Path analysis can calculate the magnitude of the direct effect and aims to calculate the indirect effect through intervening variables, which in this study also wants to prove whether job satisfaction can be a variable that mediates between discipline and motivation on employee performance. Furthermore, the Sobel test is needed to test the hypothesis on the indirect effect.

\section{Results}

Before presenting the results of the path analysis test and hypothesis testing, first presented the instrument testing results with validity and reliability tests. This validity test is conducted to measure the validity level of the questionnaire used. The standard of validity uses the corrected item-total correlation. If the questionnaire's corrected item-total correlation value on the questionnaire is greater than 0.3 , the statement item on the questionnaire is valid. The validity test results are as shown in Table 1, where all indicators have a corrected item-total correlation value that is higher than the standard 0.3 . Therefore, all statement items on the studied variables are assumed to be valid.

Table 1. Result of Validity and Reliability Test 


\begin{tabular}{cccc}
\hline Variable & Item & $\begin{array}{c}\text { Corrected item-total } \\
\text { correlation }\end{array}$ & Cronbach's Alpha \\
& X1.1 & 0.773 & \\
Discipline & X1.2 & 0.787 & 0.924 \\
(X1) & X1.3 & 0.832 & \\
& X1.4 & 0.833 & \\
& X1.5 & 0.783 & 0.902 \\
Work Motivation (X2) & X2.1 & 0.708 & \\
& X2.2 & 0.772 & \\
& X2.4 & 0.786 & 0.921 \\
Job Satisfaction & X2.5 & 0.821 & \\
(Y1) & Y1.1 & 0.699 & \\
& Y1.2 & 0.868 & \\
& Y1.3 & 0.812 & \\
& Y1.4 & 0.753 & \\
Employee Performance & Y1.5 & 0.789 & \\
(Y2) & Y2.1 & 0.761 & \\
& Y2.3 & 0.775 & \\
& Y2.4 & 0.888 & \\
& Y2.5 & 0.873 & \\
& & 0.851 & \\
& & 0.874 & \\
& & & \\
& & &
\end{tabular}

Then, for reliability using Cronbach's alpha technique. The reliability test results shown in Table 1 show the Cronbach's alpha value for the work discipline variable of 0.924 ; work motivation variable of 0.902 ; job satisfaction variable of 0.921 ; and employee performance variable of 0.945 . These results indicate that all variables have good reliability based on cronbach alpha scorest which meets the rule of thumb $>0.70$ [25].

Furthermore, the path analysis results to examine the direct and indirect effects of work discipline and work motivation on employee satisfaction and performance, the results can be seen in Table 2 below.

Table 2. Result of Hypothesis Test

\begin{tabular}{ccccc}
\hline Path & Standardized Estimate & C.R & p-value & Result \\
\hline $\mathrm{X} 1 \rightarrow \mathrm{Y} 1$ & 0.322 & 4.872 & 0.000 & H1 Support \\
$\mathrm{X} 2 \rightarrow \mathrm{Y} 1$ & 0.628 & 9.492 & 0.000 & H2 Support \\
$\mathrm{X} 1 \rightarrow \mathrm{Y} 2$ & 0.291 & 3.571 & 0.000 & H3 Support \\
$\mathrm{X} 2 \rightarrow \mathrm{Y} 2$ & 0.053 & 0.549 & 0.583 & H4 Not Support \\
$\mathrm{Y} 1 \rightarrow$ Y2 & 0.580 & 5.904 & 0.000 & H5 Support \\
$\mathrm{X} 1 \rightarrow \mathrm{Y} 1 \rightarrow$ Y2 & $0.322 \times 0.580=0.186$ & 3.563 & 0.000 & H6 Support \\
$\mathrm{X} 2 \rightarrow \mathrm{Y} 1 \rightarrow \mathrm{Y} 2$ & $0.628 \times 0.580=0.364$ & 5.208 & 0.000 & H7 Support \\
\hline
\end{tabular}




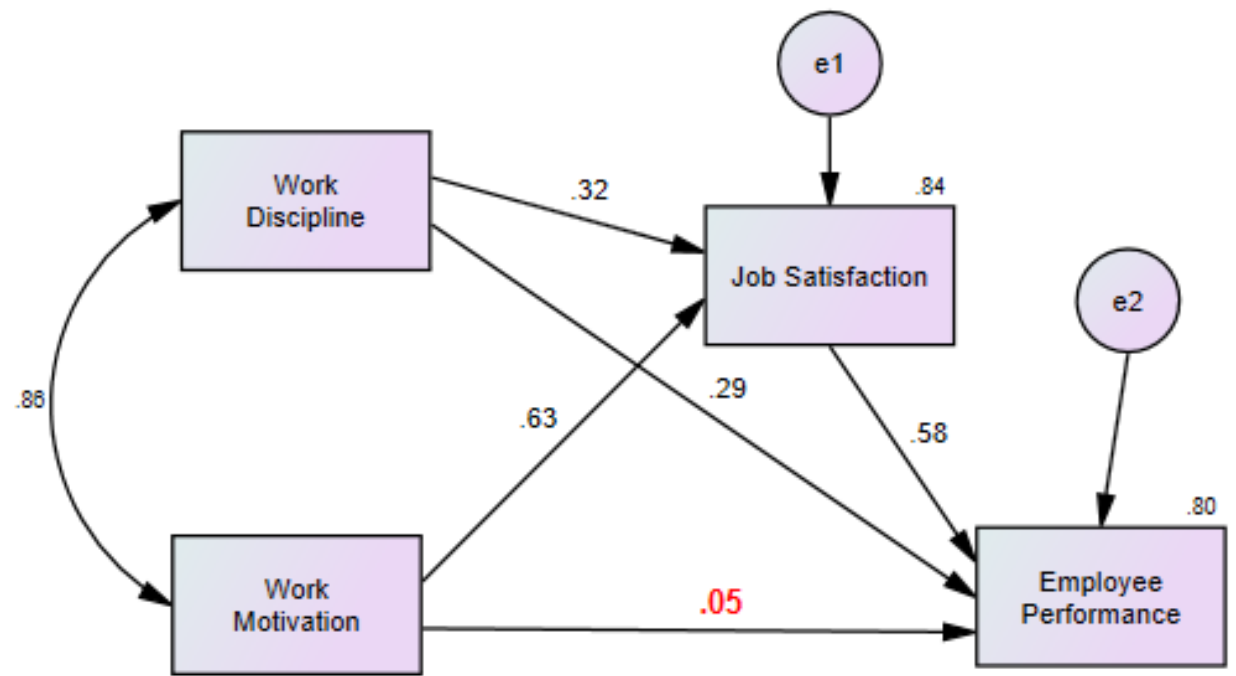

Figure 1. Path Analysis Results with Amos Program

First Hypothesis Testing on the results of path analysis with AMOS software shows that the work discipline variable path estimate score on job satisfaction has a positive effect with a positive estimate score of 0.322 and a $\mathrm{CR}$ score $>1.96$ and the p-value less than $0.05(0.000<0$, $05)$, this means that the first hypothesis has a positive and significant effect. The second hypothesis shows that the estimate value of the work motivation path to the employee performance variable has a positive effect with a positive estimate value of 0.628 and a CR score $>1.96$ and the p-value is smaller than $0.05(0.000<0.05)$, this means that the second hypothesis proven to have a positive and significant effect. The third hypothesis shows that the estimate value of the work discipline variable path to employee performance has a positive effect with a positive estimate score of 0.291 and a CR score $>1.96$ and the p-value is less than $0.05(0.000<0.05)$, this means that the third hypothesis proven to have a positive and significant effect. The fourth hypothesis shows that the estimate value of the work motivation variable path to employee performance has a positive effect with a positive estimate score of 0.053 and a CR score $<1.96$ and a $p$-value greater than $0.05(0.583>0.05)$, this means that the fourth hypothesis proven to have a positive and insignificant effect or this fourth hypothesis is rejected. Furthermore, the Fifth Hypothesis shows that the estimated path value of the job satisfaction variable on employee performance has a positive effect with a positive estimate score of 0.580 and a CR score $>1.96$ and the p-value is less than $0.05(0.000<0.05)$, this means that the fifth hypothesis is proven to have a positive and significant effect.

Hypothesis testing for indirect effects using the sobel test, with the help of an online calculator. As the results of the calculations are shown in Table 2, the Sixth Hypothesis Testing on the results of the path analysis indirectly with the sobel test shows that the work discipline variable path estimate score on employee performance through job satisfaction has a positive effect with a positive estimate score of 0.186 and a CR score $>1.96$. Moreover, the p-value is less than $0.05(0.000<0.05)$, this means that the sixth hypothesis has a positive and significant effect. Furthermore, the seventh hypothesis shows that the estimated value of the indirect influence path between work motivation on the employee performance variable has a positive effect with a positive estimate value of 0.364 and a CR score $>1.96$ and the p-value is less than 
$0.05(0.000<0.05)$, this means that the seventh hypothesis is proven to have a positive and significant effect.

\section{Discussion}

Based on the research results that have been done, it shows that work discipline and motivation are proven to have a positive and significant effect on employee job satisfaction. That is, the higher work discipline and employee motivation, the job satisfaction they feel will also increase. The findings of this study have proven that discipline and job satisfaction have a significant impact on employee performance, meaning that when employees are always disciplined at work and feel high satisfaction with their work, this will affect employee performance in the banking industry Makassar City. This finding also reinforces previous research conducted by [7], [11], [12] which revealed that applying good discipline will significantly improve employee performance, as well as research by [7]-[9] who found that job satisfaction has a positive and significant effect on employee performance.

However, this research refutes the belief that high performance is influenced by the increasing work motivation of employees [14]-[16]. Where, the researchers found that it turns out that high work motivation is not significant or has a relatively small effect in improving employee performance. However, if this is accompanied by high job satisfaction, it can be seen that motivation will have a significant impact on improving performance. In this case, the higher the employee's work motivation followed by an increase in job satisfaction, the employee's performance will also increase. Likewise, the indirect effect between discipline on performance is that job satisfaction plays an important role in mediating the influence between the two variables.

\section{Conclusion}

In several previous studies, it was stated that discipline and work motivation variables could have a positive and significant impact on increasing employee job satisfaction. Through this study, the explanation and affirmation of this case reinforce the existing concept. Likewise, the effect between discipline and job satisfaction on employee performance is proven to have a positive and significant effect. There are different findings in terms of the influence between motivation on employee performance in the banking industry in Makassar City, where work motivation does not significantly affect employee performance. However, it is different when job satisfaction acts as a mediating variable, wherein the discipline and work motivation have a significant impact on improving employee performance through job satisfaction. Lastly, this study aims to contribute in the context of the banking industry and a more general discussion of topics related to efforts to improve employee performance both theoretically and empirically.

\section{References}

[1] Gridwichai, P.Kulwanich, A.Piromkam, B.and Kwanmuangvanich, P.: Role Of Personality Traits On Employees Job Performance In Pharmaceutical Industry In Thailand, Syst. 
Rev. Pharm., vol. 11, no. 3, pp. 185-194, (2020).

[2] Jalagat, R.: Determinants Of Job Stress And Its Relationship On Employee Job Performance, Am. J. Manag. Sci. Eng., vol. 2, no. 1, pp. 1-10, (2017).

[3] Jankingthong, K. and Rurkkhum, S.: Factors Affecting Job Performance: A Review Of Literature, Humanit. Arts Soc. Sci. Stud. (FORMER NAME SILPAKORN Univ. J. Soc. Sci. Humanit. ARTS), pp. 115-128, (2012).

[4] Khtatbeh, M. M.Mahomed, A. S. B.bin Ab Rahman, S.and Mohamed, R.: The Mediating Role Of Procedural Justice On The Relationship Between Job Analysis And Employee Performance In Jordan Industrial Estates, Heliyon, vol. 6, no. 10, p. e04973, (2020).

[5] Sagala, E. J. and Rivai, V.: Manajemen Sumber Daya Manusia Untuk Perusahaan Dari Teori Ke Praktik. Jakarta: PT. Raja Grafindo Persada, (2009).

[6] Kertabudi, I. S.: Aripin.(2015). Effect Organizational Commitment And Job Satisfaction On Employees Performance At Cibabat Hospital, Cimahi City West Java, Aust. J. Basic Appl. Sci., vol. 9, no. 33, pp. 346-351.

[7] Andjarwati, T. et al:: The Effect Of Osha, Work Environment And Work Discipline On Employee Satisfaction And Employee Performance, Arch. Bus. Res., vol. 7, no. 11, (2019).

[8] Eliyana, A. and Ma'arif, S.: Job Satisfaction And Organizational Commitment Effect In The Transformational Leadership Towards Employee Performance, Eur. Res. Manag. Bus. Econ., vol. 25, no. 3, pp. 144-150, (2019).

[9] Khan, A. H.Nawaz, M. M.Aleem, M.and Hamed, W.: Impact Of Job Satisfaction On Employee Performance: An Empirical Study Of Autonomous Medical Institutions Of Pakistan, African J. Bus. Manag., vol. 6, no. 7, pp. 2697-2705, (2012).

[10] Sutrisno, E.: Manajemen Sumber Daya Manusia, Edisi Ke-Delapan, Jakarta: Kencana, vol. 5, no. 1, (2016).

[11] Mangkunegara, A. P. and Waris, A.: Effect Of Training, Competence And Discipline On Employee Performance In Company (Case Study In PT. Asuransi Bangun Askrida), Procedia-Social Behav. Sci., vol. 211, pp. 1240-1251, (2015).

[12] Sulila, I.: The Effect Of Discipline And Work Motivation On Employee Performance, BTPN Gorontalo, Int. J. Appl. Bus. Int. Manag., vol. 4, no. 3, pp. 121-131, (2019).

[13] Wibowo:Manajemen kinerja, 3th Editio. Jakarta: Rajawali Pers, (2005).

[14] Sherwani, K. H.: Impact Of The Academician's Perception Of Organizational Justice On Contextual Performance:(The Case Of Academicians Of Two Private Universities In Erbil City)., Int. J. Pure Appl. Math., vol. 118, no. 20, pp. 4861-4873, (2018).

[15]Dharma, Y.: The Effect Of Work Motivation On The Employee Performance With Organization Citizenship Behavior As Intervening Variable At Bank Aceh Syariah, in Proceedings of MICoMS 2017, Emerald Publishing Limited, (2018).

[16] Seng, N. and Arumugam, T.: Financial Reward And Motivation Toward Employee Job Performance In The Hospitality Industry In Klang Valley, Electron. J. Bus. Manag., vol. 2, no. 1, pp. 51-60, (2017).

[17] Larasati, S. and Gilang, A.: Pengaruh Motivasi Kerja Terhadap Kinerja Karyawan Wilayah Telkom Jabar Barat Utara (Witel Bekasi), J. Manaj. dan Organ., vol. 5, no. 3, pp. 200 213, (2014).

[18]Paoki, E. P.Saerang, D. P. E.and Pangemanan, S. S.: The Effect Of Work Discipline And Team Work On Employee Performance (Case Study At PT. Bahasa Technology Solutions), J. EMBA J. Ris. Ekon. Manajemen, Bisnis dan Akunt., vol. 5, no. 2, (2017).

[19] Sardjana, E.Sudarmo, S.and Suharto, D. G.: The Effect Of Remuneration, Work Discipline, Motivation On Performance, Int. J. Multicult. Multireligious Underst., vol. 5, no. 6, 
pp. 136-150, (2019).

[20] Dhermawan, A. A. N. B.Sudibya, I. G. A.and Utama, I. W. M.: Pengaruh Motivasi, Lingkungan Kerja, Kompetensi, Dan Kompensasi Terhadap Kepuasan Kerja Dan Kinerja Pegawai Di Lingkungan Kantor Dinas Pekerjaan Umum Provinsi Bali, Matrik J. Manajemen, Strateg. Bisnis dan Kewirausahaan, (2012).

[21] Davis, K. and Newstrom:Newstrom. 2000, Perilaku Dalam Organisasi. Jakarta: Erlangga. [22] Riduwan, M. B. A.: Skala Pengukuran Variabel-Variabel Penelitian, Alf. Bandung, (2007).

[23] Hendri, E.: Pengaruh Lingkungan Kerja Fisik Dan Non Fisik Terhadap Kepuasan Kerja Karyawan Pada Pt Asuransi Wahana Tata Cabang Palembang, J. Media Wahana Ekon., vol. 9, no. 3, pp. 1-16, (2012).

[24] Mangkunegara, A. A. A. P.:Manajemen sumber daya manusia perusahaan. PT. Remaja Rosdakarya, (2010).

[25] Ghozali, I.: Econometrics Theory, Concepts, And Applications With SPSS 17, Semarang Diponegoro Univ. Publ. Agency, (2017). 